\title{
Morphological divergence in Indian oil sardine, Sardinella longiceps Valenciennes, 1847- Does it imply adaptive variation?
}

\author{
By S. Sukumaran, A. Gopalakrishnan, W. Sebastian, P. Vijayagopal, S. Nandakumar Rao, N. Raju, S. Ismail, \\ E. M. Abdussamad, P.K. Asokan, K. P. Said Koya and P. Rohit
}

Central Marine Fisheries Research Institute, Kochi, Kerala, India

\begin{abstract}
Summary
The Indian oil sardine, Sardinella longiceps, is an important pelagic species in Indian waters, and shows divergent morphology while in sympatry. The reasons behind this divergent morphology were investigated using morphometric, genetic and nutritional analyses. Twenty-one morphometric characters (as percentage of standard length) and eight meristic characters were studied in the three variants to assess whether they are significantly diverged. Distinct clustering of morphotypes was evident in the principal component analysis on log-transformed ratios of morphological characters with $\mathrm{PC} 1$ and PC2, explaining $50.7 \%$ and $17.6 \%$ of the total morphological variation, respectively. PC1 was highly correlated with the distance from snout to anal origin, depth at dorsal, distance from snout to pelvic and distance from snout to first dorsal. PC2 was highly correlated with head length, caudal width and anal depth. Analysis of similarities (ANOSIM) was conducted using log-transformed morphometric ratios, with the results showing the clusters to be well differentiated $(\mathrm{R}=0.511 ; \mathrm{P}<0.01)$. Similarity of percentage analysis (SIMPER) analysis showed that the differences in depth at the dorsal, anal base length, caudal width, distance from pelvic to anal origin, anal depth and eye diameter accounted for $52 \%$ of variations between variant 1 and 2 . Differences in caudal width, distance from pelvic to anal origin, anal base length, depth at dorsal and anal depth accounted for $56 \%$ of the variation between variant 2 and 3. Differences in caudal width, eye diameter, anal base length, anal depth, distance from pelvic to anal origin accounted for $50 \%$ of the variation between variant 1 and 3 . Genetic divergence was not significantly based on mitochondrial cytochrome $\mathrm{c}$ oxidase I (COI) or control region sequences. Proximate composition analyses showed significantly high fat content in variants $1 \& 3$ and significantly high protein content in variant 2 , probably due to dissimilar dietary preferences. The study shows that morphotypes of the Indian oil sardine may be the result of divergent selection and adaptive variations, which need further investigation using a long-term sampling design.
\end{abstract}

\section{Introduction}

The Indian oil sardine, Sardinella longiceps, is one of the most important pelagic fishes in Indian waters with a wide range of distribution and contributed to $16 \%$ of total fish landings in India in 2014 (CMFRI (Central Marine Fisheries Research Institute), Kochi, 2014), with a major contribution from the Malabar upwelling zone (31.8\%). A fast-growing species attaining sexual maturity at the end of its first year, the fishery consists of 0- and 1-year classes (Devaraj et al., 1997) although the life span is 3-4 years. The Indian $S$. longiceps fishery showed dramatic fluctuations on a decadal scale, with periodic extinctions and recolonizations (Longhurst and Wooster, 1990; Xu and Boyce, 2009). Spawning and consequent recruitment of small pelagic fishes are highly dependent on complex oceanographic parameters such as upwelling, sinking, formation of eddies, etc. hence, localized extinctions are always possible (Grant and Bowen, 1998).

Identification of the number of stocks or management units is very pertinent for effective management and sustainability. Very often the stock boundaries are confounded by migration and the stock structuring of marine pelagic fishes is generally weak. Genetic stock structure estimates are based on neutral loci and most well-studied marine pelagic fishes are panmictic with very low genetic differentiation (Volckaert, 2013). Even this low genetic differentiation is found to be meaningful on an ecological time scale (Knutsen et al., 2003, 2011).

Although genetic estimates show lack of a population structure, marine fishes can exist as locally adapted populations and with gene flow between them (Hutchings et al., 2007). The genetic imprints of this type of adaptation may be more evident in functional genes, which have undergone selection in various habitats (Defaveri and Merila, 2013). Variations in gene expression may also play a major role in shaping adaptation to different environmental conditions and also in the evolution of plastic responses (Bernatchez et al., 2010). Phenotypic plasticity in response to environmental conditions has been reported in several pelagic fishes (Baumann and Conover, 2010). The fishes are capable of adapting to fluctuating environmental conditions by altering their temperature sensitivity, reproductive timing or physiological parameters. It is also possible to have locally acclimated specialists in the same metapopulation (Sultan and Spencer, 2002). Several studies have reported phenotypical differentiation among connected marine populations (Cadrin, 2000; O'Reilly and Horn, 2004), but the correlation between adaptation and neutral genetic variation may not be observed in most of the cases. Adaptive phenotypic divergence precedes speciation and is the outcome of divergent natural selection 
in heterogeneous environments (Bernatchez et al., 2010). Morphological differences in white fish (Coregonus genus) populations sympatrically inhabiting lakes located in the St. John River drainage have been studied extensively over a long time period by comparing the extent of divergence in many phenotypic traits (Qst) with the extent of divergence in genetic characters using microsatellite markers (Fst). The study provided evidence that gill rakers, growth and swimming behaviour evolved under the effect of divergent selection (Rogers et al., 2002). Phenotypic divergence by way of natural selection and its relation to gene expression has also been investigated (Wray, 2007; Fay and Wittkopp, 2008).

Feeding morphology and ecology has a major role in shaping the morphological differences (Albertson et al., 2003) as exemplified in the speciation and divergence of cichlid fishes of Lake Malawi. It is difficult to identify the gene or gene complexes involved in morphological complexities and some studies have tried to address this by using quantitative genetic tools (Bernatchez et al., 2010 and references therein). Quantitative trait locus (QTL) effects that co-occur consistently with divergent selection on traits associated with that particular morphological character will provide some insights into the relationship between genetics and morphology (Gilad et al., 2008), but in most cases such character complexes are associated with pleiotropy, involvement of more than one gene.

The Indian oil sardine may exist as environmentally heterogeneous metapopulations with plastic types as well as local specialists. Devanesan and Chidambaram (1943) reported morphological plasticity in the Indian oil sardine by comparing sardines from Bombay, Karachi, Muscat, Aden, Karwar and Malabar, and recording variations in lengths of the head and tail; they concluded that there were different races in the population, mainly the Karwar race, Malabar and BombayKarachi race, Muscat race, and the Aden race. However, many of these morphological variants are co-occurring, which may be associated with their dietary and habitat preferences. It is also important to understand the adaptive variation in this species to devise conservation strategies for those locally adapted species, as they have higher fitness values in that particular environment. Hence the present study aimed to understand whether the morphological differentiation was significant and whether they were genetically diverged. We could visually differentiate 2 forms from commercial landings along the Kerala coast; the third variant was Indian oil sardines imported from Oman and which are available in fish markets. We analysed the morphometric and meristic characteristics of the three variants. Analysing the sequences of mitochondrial COI and control region sequences ascertained the genetic similarities. The proximate composition of the three morphological variants was also studied regarding their nutritional status as well as to derive some insights into the importance of feeding and nutrition on their morphology.

\section{Materials and methods}

\section{Sample collection and morphometric analyses}

Thirty individuals each of morphologically different Indian oil sardine $S$. longiceps samples were collected. Variant 1 and
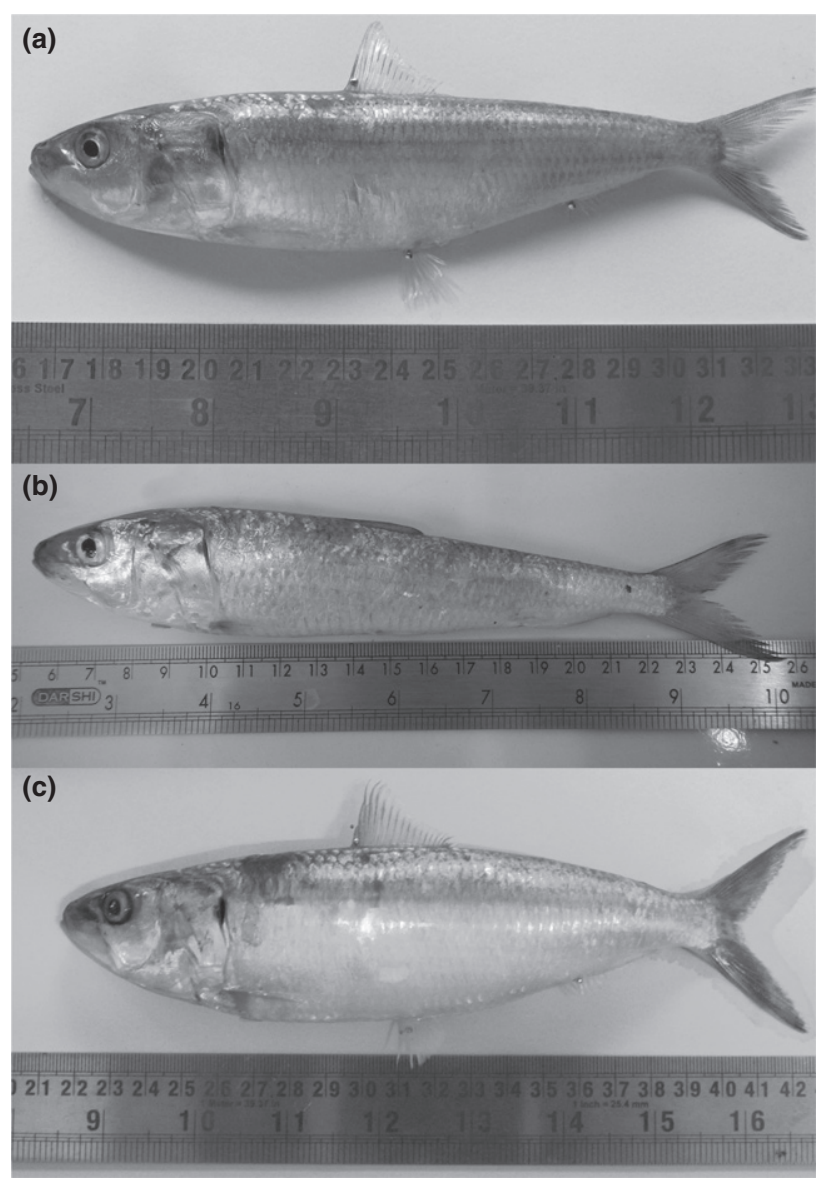

Fig. 1. Three morphological variants of Indian oil sardine, Sardinella longiceps (males) collected during July 2014 belonging to the same maturity condition (maturity stage 3 ) (a) variant 1 (b) variant 2 (c) variant 3

2 were termed as stout and slender sardines, respectively, based on their visual appearance (Fig. 1). Variant 3 was available only from the Gulf of Oman and thus coined as Oman sardines. Variants 1 and 2 were collected from Calicut (Puthiappa village) by ring seines (a mini-sized purse seine mesh between 18-22 mm) operated near the coast; fishes of variant 3 from the Gulf of Oman were purchased from a local market (imported from Oman and collected using beach seines of mesh sizes between $21-23 \mathrm{~mm}$ ). All three variants were collected in July 2014. Range of standard length for all variants was $15-20 \mathrm{~cm}$. There were 13 females and 17 males in the variant 1 cohort, 16 females and 14 males in variant 2, and 14 females and 16 males in variant 3 . Males and females belonged to stage III maturity condition (Antony Raja, 1967) of males with a thickened white testes, vas deferens size not more than $1.5 \mathrm{~cm}$ and occupying about $3 / 4$ ths of the body cavity, and females with oviducts extending to more than half of the body cavity but less than $3 / 4$ ths and the ova visible to the naked eye. We measured 21 morphometric characters and eight meristic characters in all the samples. All morphological characters were then converted to percentage of standard length (SL). A principal 
component analysis was performed on natural log-transformed ratios of significantly different morphological characters using PRIMER v5, which separated morphological variations into linear combinations of variables that describe body shape. Along with this, analysis of similarities (ANOSIM) and similarity of percentage analysis (SIMPER) were carried out on log-transformed morphometric ratios in PRIMER v5 to assess the percentage contribution of morphometric ratios to the overall variations in body shape.

\section{Genetic analyses; DNA extraction and amplification of the Cytochrome C Oxidase I gene and control region}

Total DNA was extracted from muscle tissue using a standard phenol/chloroform extraction protocol and ethanol precipitation. Universal primers for amplification of the Cytochrome C Oxidase 1 region of marine fishes (Folmer et al., 1994) were used for amplifying a $700 \mathrm{bp}$ region of the cytochrome c oxidase 1 gene, and universal primers for amplification of the complete mitochondrial control region of marine fishes (Cheng et al., 2012) were used for amplifying the control region. PCR amplifications were carried out in a $25 \mu \mathrm{l}$ reaction mixture containing $10 \mathrm{~mm}$ Tris- $\mathrm{HCl}, \mathrm{pH}$ 8.3, $50 \mathrm{~mm} \mathrm{KCl}, 1.5 \mathrm{~mm} \mathrm{MgCl}_{2}, 200 \mu \mathrm{M}$ of each dNTP, $0.2 \mu \mathrm{M}$ of each oligonucleotide, 1 unit of Taq DNA polymerase and $50 \mathrm{ng}$ of template DNA. The PCR reaction was carried out in a Biorad T100 thermocycler (Biorad, USA) programmed for an initial denaturation at $94^{\circ} \mathrm{C}$ for $4 \mathrm{~min}$ followed by 33 cycles of; denaturation at $94^{\circ} \mathrm{C}$ for $30 \mathrm{~s}$, annealing at $42^{\circ} \mathrm{C}$ for $30 \mathrm{~s}$, extension at $72^{\circ} \mathrm{C}$ for $40 \mathrm{~s}$ and a final extension at $72^{\circ} \mathrm{C}$ for $7 \mathrm{~min}$ for amplification of $\mathrm{CO} 1$ gene. For amplifiying control region, an initial denaturation at $94^{\circ} \mathrm{C}$ for $4 \mathrm{~min}$ followed by 35 cycles of; denaturation at $94^{\circ} \mathrm{C}$ for $30 \mathrm{~s}$, annealing at $48^{\circ} \mathrm{C}$ for $30 \mathrm{~s}$, extension at $72^{\circ} \mathrm{C}$ for $55 \mathrm{~S}$ and a final extension at $72{ }^{\circ} \mathrm{C}$ for $7 \mathrm{~min}$. Purification of the PCR product was carried out using the Qiagen PCR purification kit and sequenced with LCO1490 and HC02198 (Folmer et al., 1994) primers using the BigDye Terminator Sequencing Ready Reaction v3.0 kit (Applied Biosystems) following instructions of the manufacturer. Sequencing was carried out on an ABI 3730 automated sequencer. A 650 bp region of the cytochrome $\mathrm{C}$ oxidase gene region and a $762 \mathrm{bp}$ region of the control region of S. longiceps was amplified in all sampled individuals for phylogenetic analysis. All partial sequences of $S$. longiceps $\mathrm{CO} 1$ and the control region were deposited in GenBank with the accession no: KT461672-KT461726. The sequences were aligned using clustal $\mathrm{W}$ in MEGA 6 and a phylogenetic tree was constructed using the UPGMA method with 1000 bootstraps. The tree was rooted with sequences of Sardinella albella retrieved from GenBank.

\section{Proximate composition analysis}

Three whole male fishes each belonging to variant 1, 2 and 3 (total 9) were analysed for percentage of moisture, crude protein, crude fat, crude ash, crude fibre, acid insoluble ash and nitrogen free extract on a dry and wet matter basis. Moisture content was determined by drying the flesh at $105^{\circ} \mathrm{C}$ for
5-6 h to a constant weight. Fat was estimated by extracting the same with ether in a soxhlet extractor for a period of 10$12 \mathrm{~h}$ or more. Nitrogen in the flesh was estimated by the micro-kjeldahl nitrogen estimation method and the nitrogen value multiplied by the factor 6.25 for protein values. Ash content was estimated by igniting a known weight of sample in silica crucible at $600^{\circ} \mathrm{C}$ for $6 \mathrm{~h}$. Crude fibre content was estimated by dissolving the sample in sulphuric acid and sodium hydroxide solutions and the final residue calcined. The difference in weight after calcination gives the quantity of fibre present in the sample. The acid-insoluble ash was determined by dissolving the ash with $5 \mathrm{~N} \mathrm{HCl}$ and filtering the residue with Whatman 42 filter paper. Nitrogen-free extract was determined after subtracting the values of crude protein, crude fat, crude ash and crude fibre from total dry matter content (AOAC, 1990).

\section{Results}

Among the seventeen morphological characteristics measured as percentage of standard length, fifteen characteristics were significantly different among the three variants (Table 1); meristic characters did not differ significantly. A principal component analysis (PCA) using the fifteen significantly different morphological characteristics showed morphometric differentiation among the variants, with variant 2 structured again into two well-separated clusters resulting in four clusters (Table 2). The first five principal components accounted for $84 \%$ of the overall variance (PC1-50.7\%; PC2-17.6\%; PC3-6.5\%; PC4-5.2\%; PC5-4.1\%) (Table 3). PC1 was highly

Table 1

Morphological characteristics measured in three variants of Indian oil sardine Sardinell longiceps (average values as percentage of standard length)

\begin{tabular}{|c|c|c|c|c|}
\hline Sl.No & Morphometric characteristics & $\begin{array}{l}\text { Variant } \\
1\end{array}$ & $\begin{array}{l}\text { Variant } \\
2\end{array}$ & $\begin{array}{l}\text { Variant } \\
3\end{array}$ \\
\hline 1 & Head length** & 30.8 & 28.7 & 27.46 \\
\hline 2 & Snout length** & 6.76 & 5.87 & 5.92 \\
\hline 3 & Eye diameter** & 6.05 & 4.94 & 5.08 \\
\hline 4 & Inter orbital width** & 6.62 & 5.46 & 7 \\
\hline 5 & $\begin{array}{l}\text { Distance from snout to } 1 \text { st } \\
\text { dorsal** }\end{array}$ & 47.36 & 44.01 & 45.85 \\
\hline 6 & $\begin{array}{l}\text { Distance from snout to } \\
\text { pectoral* }\end{array}$ & 29.43 & 27.6 & 27.95 \\
\hline 7 & $\begin{array}{l}\text { Distance from snout to } \\
\text { pelvic** }\end{array}$ & 54.76 & 51.28 & 54.38 \\
\hline 8 & $\begin{array}{l}\text { Distance from snout to anal } \\
\text { origin** }\end{array}$ & 78.14 & 70.7 & 78.06 \\
\hline 9 & $\begin{array}{l}\text { Distance from pelvic to anal } \\
\text { origin** }\end{array}$ & 23.59 & 20.05 & 26.13 \\
\hline 10 & Caudal width** & 8.0 & 6.9 & 9.7 \\
\hline 11 & Depth at first dorsal** & 24.42 & 19.03 & 24.76 \\
\hline 12 & Depth at anal origin** & 14.0 & 12.11 & 15.72 \\
\hline 13 & First dorsal height** & 12.25 & 10.7 & 11.62 \\
\hline 14 & First dorsal base length** & 13.46 & 11.6 & 13.43 \\
\hline 15 & Anal base length** & 13.19 & 10.7 & 13.35 \\
\hline 16 & Pectoral length & 14.7 & 14.0 & 14.9 \\
\hline 17 & Pelvic length & 7.7 & 7.59 & 8.23 \\
\hline
\end{tabular}

*Significant $\mathrm{P}<0.05$.

**Highly significant $\mathrm{P}<0.01$ 
Table 2

Summary of principal component analysis (eigen values and eigen vectors) calculated from 15 morphometric ratios describing body shape

\begin{tabular}{|c|c|c|c|c|c|}
\hline & $\mathrm{PC} 1$ & $\mathrm{PC} 2$ & PC3 & PC4 & PC5 \\
\hline Eigen value & 7.60 & 2.63 & 0.98 & 0.77 & 0.61 \\
\hline$\%$ variance & 50.7 & 17.6 & .5 & 5.2 & 4.1 \\
\hline $\begin{array}{l}\text { Eigen vector } \\
\text { Distance from }\end{array}$ & - & & & & \\
\hline to pectoral & & & & & \\
\hline Caudal width & -0.237 & -0.355 & -0.032 & 0.029 & -0.076 \\
\hline Depth at dorsal & -0 & -0 . & 0.046 & & 0.344 \\
\hline Depth at anal & -0.209 & -0.334 & 0.260 & 0.420 & 0.353 \\
\hline Dorsal height & -0.255 & 0.135 & -0.423 & 0.470 & -0.048 \\
\hline Dorsal basal length & -0.281 & -0.087 & -0.125 & -0.176 & -0.095 \\
\hline Head length & -0.180 & 0.480 & -0.029 & 0.039 & 0.158 \\
\hline Snout length & -0.136 & 0.223 & 0.761 & 0.312 & -0.294 \\
\hline Eye diameter & - & 0 & 0 . & & 0.458 \\
\hline Inter & -0.2 & -0.244 & 0.109 & 0 . & 0.067 \\
\hline $\begin{array}{l}\text { Distance from snout } \\
\text { to first dorsal }\end{array}$ & -0.286 & 0.248 & -0.045 & -0.354 & -0.095 \\
\hline $\begin{array}{l}\text { Distance from snout } \\
\text { to pelvic }\end{array}$ & -0.295 & .095 & -0.010 & -0.327 & -0.352 \\
\hline $\begin{array}{l}\text { Distance from snout } \\
\text { to anal origin }\end{array}$ & -0.520 & 24 & 18 & 0.089 & -0.297 \\
\hline $\begin{array}{l}\text { Distance from pelvic } \\
\text { to anal origin }\end{array}$ & -0.274 & -0.261 & -0.146 & 0.248 & -0.353 \\
\hline Anal base length & -0.260 & -0.144 & -0.024 & 0.324 & 0.252 \\
\hline
\end{tabular}

correlated with distance from snout to anal origin, depth at dorsal fin, distance from snout to pelvis and distance from snout to first dorsal fin. PC2 was highly associated with head length, caudal width and anal depth. The PCA plot showed four clusters with one cluster containing eight individuals of variant 2, well separated from other clusters of which three were females and five were males (Fig. 2). All other individuals of variants 1, 2 and 3 formed three adjacent clusters with intermediate phenotypes connecting them.

Analysis of similarities (ANOSIM) was conducted using morphometric ratios; the results showed the clusters to be well differentiated $(\mathrm{R}=0.511 ; \mathrm{P}<0.01)$. SIMPER analysis showed that the differences in depth at dorsal, anal base length, caudal width, distance from pelvic to anal origin, depth at anal and eye diameter accounted for $52 \%$ of variation between variants 1 and 2. Differences in caudal width, distance from pelvic to anal origin, anal base length, depth at dorsal and depth at anal origin accounted for $56 \%$ of the variation between variants 2 and 3 . Differences in caudal width, eye diameter, anal base length, depth at anal, distance from pelvic to anal origin accounted for $50 \%$ of the variation between variants 1 and 3 .

The UPGMA tree constructed using cytochrome c oxidase and control region sequences did not show any clustering among the three variants, indicating their genetic similarity. Genetic distances among the morphotypes were ascertained by calculating kimura $2 \mathrm{p}$ values with $\mathrm{CO} 1$ gene sequences, and the values between variant $1 \& 2,1 \& 3$ and $2 \& 3$ were $0.3 \%, 0.1 \%$ and $0.2 \%$, respectively. These values show that they are not divergent genetically.

The crude protein content was significantly higher in variant 2 compared to variants $1 \& 3$, whereas crude fat was significantly higher in variants $1 \& 3$ compared to variant 2 on a dry matter basis (Table 3 ).

\section{Discussion}

Morphological differences have been reported in many marine pelagic species, especially in clupeids (Thomas et al., 2014). In Atlantic cod Gadus morhua, morphological differences were associated with behavioural and ecological differentiation (McAdam et al., 2012). The two behavioural types, coastal and frontal, were associated with distinct morphological characteristics such as gape of mouth, eye position and spaces between fins and depth of body. The patterns of habitat use, foraging and migratory behaviour were different in the two types (Grabowski et al., 2011). Behavioural patterns in the Indian oil sardine have yet to be investigated, hence conclusions could not be drawn regarding the variations in morphology and behaviour. Habitat preferences and dietary differences may also affect morphology, e.g. Gadus morhua, Atlantic cod around Icelandic waters had higher condition factors and a greater girth and higher aspect ratio than fishes from deeper waters (Pardoe et al., 2008; Pardoe and Marteinsdottir, 2009). In the present study, Indian oil sardines from Oman, variant 3, were heavier and with greater body depth than the two variants from Indian waters and thus indicating the presence of greater energy reserves and a good condition factor. This may also be due to the higher productivity of Oman waters, which are more temperate. Among variants 1 and 2, variant 1 was stouter in appearance

Table 3

Proximate composition of morphological variants of Indian oil sardines (males) belonging to the same maturity condition on dry matter and wet matter basis (percentage)

\begin{tabular}{|c|c|c|c|c|c|c|c|c|}
\hline $\begin{array}{l}\text { Sample } \\
\text { Name }\end{array}$ & $\begin{array}{l}\text { Dry } \\
\text { matter }\end{array}$ & Moisture & $\begin{array}{l}\text { Crude } \\
\text { protein }\end{array}$ & Crude fat & $\begin{array}{l}\text { Nitrogen } \\
\text { free extract }\end{array}$ & $\begin{array}{l}\text { Crude } \\
\text { fibre }\end{array}$ & $\begin{array}{l}\text { Crude } \\
\text { ash }\end{array}$ & $\begin{array}{l}\text { Acid Insoluble } \\
\text { ash }\end{array}$ \\
\hline \multicolumn{9}{|c|}{ (a) Dry matter basis } \\
\hline Variant1 & 100 & Nil & $57.45 \pm 0.76$ & $34.90 \pm 0.27$ & $1.86 \pm 0.57$ & $0.29 \pm 0.03$ & $5.71 \pm 0.35$ & $0.28 \pm 0.23$ \\
\hline Variant 2 & 100 & Nil & $79.39 \pm 1.17$ & $12.10 \pm 0.41$ & $0.89 \pm 0.45$ & $0.13 \pm 0.01$ & $7.47 \pm 0.73$ & $0.28 \pm 0.23$ \\
\hline Variant 3 & 100 & Nil & $55.85 \pm 3.8$ & $29.59 \pm 5.8$ & $0.56 \pm 0.37$ & $0.12 \pm 0.04$ & $13.87 \pm 2.33$ & $0.13 \pm 0.07$ \\
\hline \multicolumn{9}{|c|}{ (b) Wet matter basis } \\
\hline Variant 1 & $27.27 \pm 1.61$ & $72.72 \pm 1.61$ & $15.60 \pm 0.77$ & $9.52 \pm 0.63$ & $0.51 \pm 0.15$ & $0.08 \pm 0.01$ & $1.56 \pm 0.19$ & $0.08 \pm 0.06$ \\
\hline Variant 2 & $19.65 \pm 2.35$ & $80.34 \pm 2.36$ & $15.60 \pm 1.97$ & $2.38 \pm 0.33$ & $0.18 \pm 0.09$ & $0.03 \pm 0.005$ & $1.46 \pm 0.08$ & $0.05 \pm 0.05$ \\
\hline Variant 3 & $35.32 \pm 2.54$ & $64.67 \pm 2.55$ & $19.66 \pm 0.18$ & $10.54 \pm 2.82$ & $0.2 \pm 0.13$ & $0.04 \pm 0.01$ & $4.87 \pm 0.63$ & $0.04 \pm 0.02$ \\
\hline
\end{tabular}




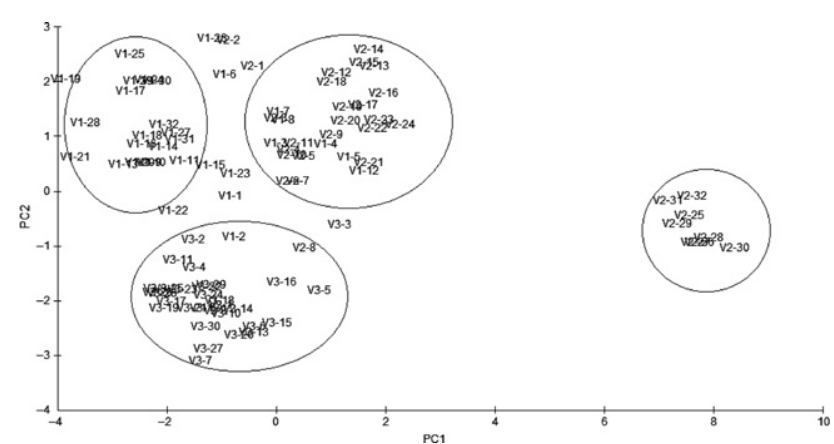

Fig. 2. Principal component analysis plot of the first vs second principal components (PC) of morphological characters in 94 Sardinella longiceps specimens

and had more fat content compared to variant 2, which was rather slender with less fat content. This definitely indicates some differences habitat/niche use and consequent differences in dietary preference.

The diet of Indian oil sardine, S. longiceps, consists of diatoms, dinoflagellates, tintinnids and zooplankton (Devaraj et al., 1997). Among the diatoms, Fragilaria oceanica has been indicated as the favourite food item since sardine abundance has been correlated with its presence in coastal waters. Sardines from Omani waters also feed on phytoplankton (Piontkovski et al., 2012). The differences in proximate composition values among the variants may be due to their dietary habits, which need further investigation using a seasonal study design.

The mitochondrial genes used in the present study, cytochrome c oxidase 1 and control region showed no significant divergence among the variants, indicating their genetic similarity. However, mitochondrial genes are presumed not to be under strong divergent selection, and hence signals of selection and adaptation and consequent changes in morphology may not be prominently observed in mitochondrial genes. Although neutral genes are widely used for species delimitation in barcoding initiatives, it has been observed that neutral genetic variation may not be direct evidence for reproductive isolation (Barraclough, 2010). The divergence in neutral genes may be indicative of either geographical isolation or ecological distinctiveness when in sympatry. In some cases such as post-zygotic isolation (Bolnick et al., 2008) mitochondrial genes will be directly involved functionally in reproductive isolation and in such cases neutral genetic variation can be taken as evidence for reproductive isolation. In the present study the neutral genetic variation was insignificant among the morphotypes, indicating their species identity. Despite their identity, the question of whether different morphotypes are capable of reproductive mixing needs further investigation using functional genes involved in reproduction. However, the presence of intermediate morphotypes may be evidence of hybridization and admixture, albeit on a limited scale.

Functional divergence in head shape, jaw morphology and body shape as a whole is under recent investigation using candidate functional genes and quantitative trait loci (Albertson et al., 2003); the major impediment in relating morphology and genetic characteristics is that many numbers of genes are involved. The divergent jaw morphology of East African cichlid fishes was studied in detail using quantitative genetic tools to identify parts of cichlid genome responsible for shape differences in the oral jaw apparatus (Albertson et al., 2003), and a strong directional selection on chromosomal segments that code for functionally important parts of craniofacial skeleton was found. Phenotypic plasticity, presence of differing phenotypes in varying environmental conditions so as to optimize fitness to that particular environment and reaction norms had been investigated using common garden experiments and microsatellite markers in Atlantic cod, Gadus morhua (Hutchings et al., 2007). Significant variations were found in reaction norms indicating adaptive phenotypic plasticity, which could not be detected in microsatellite marker patterns. In the present study the morphological differences could also be attributed to adaptive phenotypic plasticity, which optimizes fitness in particular habitats or niches and which could not be detected using neutral markers such as mitochondrial DNA. Fishes inhabit physically continuous and environmentally heterogeneous systems and hence adaptive differentiation in phenotypic characteristics like morphology provides them with some evolutionary advantages. Morphological differences observed in the Indian oil sardine may also be the result of adaptive differentiation to maximize fitness to a particular habitat and thus optimize habitat use. None of the previous studies examined the morphotypes or adaptive variations and ecology of Indian oil sardine. This study is not without its own limitations, mainly due to a lack of sound knowledge regarding habitat, dietary preferences and depth preferences of $S$. longiceps. This is a baseline study; further investigation on evolutionary adaptations, feeding strategies and the ecology of the Indian oil sardine should be carried out by adapting a long-term seasonal study design.

\section{Acknowledgements}

This work was carried out under the institute project MBTD/GEN/28 receiving funding support from the Indian Council of Agriculture Research. The authors would like to thank the Head, Marine Biotechnology Division, CMFRI and Director, CMFRI for providing facilities for carrying out this work.

\section{References}

Albertson, R. C.; Streelman, J. T.; Kocher, T. D., 2003: Directional selection has shaped the oral jaws of Lake Malawi cichlid fishes. Proc. Natl Acad. Sci. USA 100, 5252-5257.

Antony Raja, B. T., 1967: Some aspects of spawning biology of Indian oil-sardine, Sardinella longiceps Valenciennes. Indian J. Fish., 11, 45-120.

AOAC., 1990: Official methods of analyses of the association of official analytical chemists, 14th edn., Vol. 1. Association of official analytical chemists, Arlington, VA.

Barraclough, T. G., 2010: Evolving entities: towards a unified framework for understanding diversity at the species and higher levels. Philos. Trans. R. Soc. Lond. B. Biol. Sci. 365, 1801-1813.

Baumann, H.; Conover, D., 2010: Adaptation to climate change: contrasting patterns of thermal-reaction-norm evolution in Pacific versus Atlantic silversides. Proc. R. Soc. B 278, 2265-2273. 
Bernatchez, L.; Renaut, S.; Whiteley, A. R.; Derome, N.; Jeukens, J.; Landry, L.; Lu, G.; Nolte, A. W.; Ostbye, K.; Rogers, S. M.; St-Cyr, J., 2010: On the origin of species: insights from the ecological genomics of lake whitefish. Philos. Trans. R. Soc. Lond. B. Biol. Sci. 365, 1783-1800.

Bolnick, D. I.; Turelli, M.; Lopez-Fernadez, H.; Wainwright, P. C.; Near, T. J., 2008: Accelerated mitochondrial evolution and 'Darwin's corollary': asymmetric viability of reciprocal F1 hybrids in centrarchid fishes. Genetics 178, 1037-1048.

Cadrin, S. X., 2000: Advances in morphometric identification of fishery stocks. Rev. Fish. Biol. Fisher. 10, 91-112.

Cheng, Y.; Wang, R.; Sun, Y.; Xu, T., 2012: The complete mitochondrial genome of the small yellow croaker and partitioned Bayesian analysis of Sciaenidae fish phylogeny. Genet. Mol. Biol. 35, 191-199.

CMFRI (Central Marine Fisheries Research Institute), Kochi, 2014: CMFRI Annual Report 2013-2014. Kochi, CMFRI, pp. 279.

Defaveri, J.; Merila, J., 2013: Evidence for adaptive phenotypic differentiation in Baltic Sea sticklebacks. J. Evol. Biol. 26, 17001715.

Devanesan, D. W.; Chidambaram, K. 1943: On the alleged existence of races in the population of the oil sardines, Sardinella longiceps in the Arabian Sea. Proceedings of the 30th Indian Science Congress, Calcutta (Abstracts), p. 25.

Devaraj, M.; Kurup, K.N.; Pillai, N.G.K.; Balan, K.; Vivekanandan, E.; Sathiadas, R., 1997: Status, prospects and management of small pelagic fisheries of India. In: Small pelagic resources and their fisheries in the Asia-Pacific region. Proceedings of APFIC working party on Marine Fisheries. M. Devaraj and P. Martosubroto (Eds). RAP Publishers, Thailand, pp. 91-181.

Fay, J. C.; Wittkopp, P. J., 2008: Evaluating the role of natural selection in the evolution of gene regulation. Heredity 100, 191199.

Folmer, O.; Black, M.; Hoeh, W.; Lutz, R.; Vrijenhoek, R., 1994: DNA primers for amplification of mitochondrial cytochrome $\mathrm{c}$ oxidase subunit I from diverse metazoan invertebrates. Mol. Mar. Biol. Biotechnol. 3, 294-299.

Gilad, Y.; Rifkin, S. A.; Pritchard, J. K., 2008: Revealing the architecture of gene regulation: the promise of eQTL studies. Trends Genet. 24, 408-415.

Grabowski, T. B.; Thorsteinsson, V.; McAdam, B. J.; Marteinsdottir, G., 2011: Evidence of segregated spawning in a single marine fish stock: sympatric divergence of ecotypes in Icelandic cod? PLoS ONE 6, e17528.

Grant, W. S.; Bowen, B. W., 1998: Shallow population histories in deep evolutionary lineages of marine fishes: insights from sardines and anchovies and lessons for conservation. J. Hered. 89, 415-426.

Hutchings, J. A.; Swain, D. P.; Rowe, S.; Eddington, J. D.; Puvanendran, V.; Brown, J. A., 2007: Genetic variation in life-history reaction norms in a marine fish. Proc. R. Soc. B 274, 1693-1699.
Knutsen, H.; Jorde, P. E.; André, C.; Stenseth, N. C., 2003: Finescaled geographical population structuring in a highly mobile marine species: the Atlantic cod. Mol. Ecol. 12, 385-394.

Knutsen, H.; Olsen, E. M.; Jorde, P. E.; Espeland, S. H.; Andre, C.; Stenseth, N. C., 2011: Are low but statistically significant levels of genetic differentiation in marine fishes biologically meaningful? A case study of Atlantic cod. Mol. Ecol. 20, 768-783.

Longhurst, A. R.; Wooster, W. S., 1990: Abundance of oil sardine (Sardinella longiceps) and upwelling on the southwest coast of India. Can. J. Fish Aquat. Sci. 47, 2407-2419.

McAdam, B. J.; Grabowski, T. B.; Marteinsdottir, G., 2012: Identification of stock components using morphological markers. J. Fish Biol. 81, 1447-1462.

O'Reilly, K. M.; Horn, M. H., 2004: Phenotypic variation among populations of Atherinops affinis (Atherinopsidae) with insights from a geometric morphometric analyses. J. Fish Biol. 64, 11171135 .

Pardoe, H. E.; Marteinsdottir, G., 2009: Contrasting trends in two condition indices: bathymetric and spatial variation in autumn condition of Icelandic cod Gadus morhua. J. Fish Biol. 75, 282289.

Pardoe, H. E.; Thordarson, G.; Marteinsdottir, G., 2008: Spatial and temporal trends in condition of Atlantic cod (Gadus morhua) on the Icelandic shelf. Mar. Ecol. Prog. Ser. 362, 261-267.

Piontkovski, S. A.; Al-Oufi, H. S.; Al-Jufaili, S., 2012: Seasonal and interannual changes of Indian oil sardine, Sardinella longiceps landings in the governorate of Muscat (the sea of Oman). Mar. Fish. Rev. 76, 50-59.

Rogers, M. R.; Gagnon, V.; Bernatchez, L., 2002: Genetically based phenotype-environment association for swimming behaviour in lake whitefish ecotypes (Coregonus clupeaformis Mitchill). Evolution 56, 2322-2329.

Sultan, S. E.; Spencer, H. G., 2002: Metapopulation structure favors plasticity over local adaptation. Am. Nat. 160, 271-283.

Thomas, R. C.; Willette, D. A.; Carpenter, K. E.; Santos, M. D., 2014: Hidden diversity in Sardines: genetic and morphological evidence for cryptic species in the Goldstripe Sardinella, Sardinella gibbosa (Bleeker 1849). PLoS ONE 9, 1-10.

Volckaert, F. A. M., 2013: Flat fish stocks in an ecosystem and evolutionary perspective. J. Sea Res. 75, 19-32.

Wray, G. A., 2007: The evolutionary significance of cis-regulatory mutations. Nat. Rev. Genet. 8, 206-216.

$\mathrm{Xu}, \mathrm{C} . ;$ Malabar Coast: density dependence and environmental effects. Fish Oceanogr. 18, 359-370.

Author's address: Sandhya Sukumaran, Central Marine Fisheries Research Institute, Post Box No: 1603, Ernakulam North P.O., Kochi, Kerala, India.

E-mail: sukumaransandhya@yahoo.com 